\title{
PHILOSOPHY
}

\author{
THE JOURNAL \\ OF
}

THE ROYAL INSTITUTE OF PHILOSOPHY

\author{
EDITED BY \\ H. B. AGTON \\ ASSISTED BY \\ G. N. A. VESEY
}

VOL. XLIII-1968

LONDON:

MACMILLAN \& CO., LIMITED

LITTLE ESSEX STREET, W.G.2

1968 


\section{CONTENTS OF VOLUME XLIII}

\section{ARTICLES}

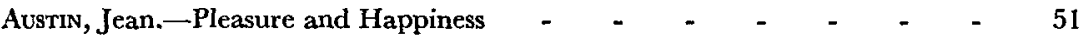

BARRy, Brian.-Warrender and his Critics - - - - - - - 117

BEST, A. E.-Misleading Questions and Irrelevant Answers in Berkeley's Theory

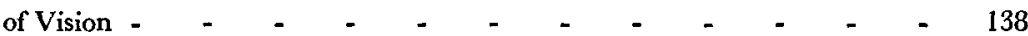

COOPER, D. E.-Collective Responsibility - - - - - - - - 258

Dunv, John.--The Identity of the History of Ideas - $\quad-\quad-\quad-\quad$ - 85

D'Entréves, A. P.-On the Nature of Political Obligation - - - - 309

Halliday, R. J. - Some Recent Interpretations of John Stuart Mill - $\quad$ - 1

Holls, Martin.-Reason and Ritual - - $\quad$ - $\quad$ - $\quad$ - $\quad$ - $\quad$ - $\quad$ - 231

Louch, A. R.-Sins and Crimes - - $\quad$ - $\quad-\quad$ - $\quad$ - $\quad$ - $\quad$ - 38

McCloskex, H. J.-Some Arguments for a Liberal Society - - - - $\quad 324$

Newelt, R. W.-Ethics and Description - - - - - - $\quad$ - 360

PRATT, Vernon. - The Inexplicable and the Supernatural - $-\quad$ - $\quad 248$

Rosen, Frederick.-Piety and Justice: Plato's 'Euthyphro' - _ - - 105

SMART, Alwynne--Mercy - - $\quad$ - $\quad$ - $\quad$ - $\quad$ - $\quad$ - $\quad$ - $\quad 345$

Spence, G. W.--The Psychology Behind J. S. Mill's 'Proof' - - - $\quad$ - 18

Swingurne, R. G.-The Argument from Design - $\quad$ - $\quad$ - $\quad$ - $\quad$ - 199

TEN, C. L.-Mill on Self-Regarding Actions - - - - - - $\quad$ - 29

Velecky, L. G.-Flew on Aquinas - - - - - - - - 213

Woolnouse, Roger.-Berkeley, The Sun that I see by Day, and that which I

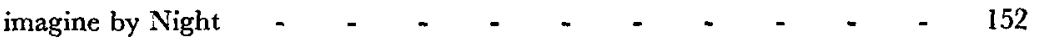

\section{DISCUSSION}

Dirman, Ilham.-Dostoyevsky as Philosopher: A short note - - - $\quad-280$

Hall, Roland.-Hume's Actual Use of Berkeley's Principles - - - - 278

HARDie, W. F. R.-Aristotle and the Freewill Problem - - - - 274

Hudson, W. D.-On Two Points against Wittgensteinian Fideism - - - 269

SANFORD, David.-McTaggart on Time - - - - - - - - 371

TURNER, John.-Diachronic Understanding - - - - - - - 284

\section{REVIEW ARTICLE}

Gustafson, Donald.-Wittgenstein's 'Zettel' - $\quad$ - $\quad$ - $\quad$ - $\quad$ - $\quad 161$ 
AcTon, H. B. What Marx Really Said (A. M. Ritchie)

ARDAL, Páll.-_Passion and Value in Hume's Treatise (Patrick Gardiner) - $\quad 177$

AYERs, M. R.-The Refutation of Determinism (R. G. Swinburne) - - $\quad 390$

Beardsley, Monroe.-Aesthetics from Classical Greece to the Present: A Short History

(Martin Eshleman) - - - - - - $\quad$ - $\quad$ - $\quad$ - 63

BennetT, Jonathan.-Kant's Analytic (D. P. Dryer) - - - - - 295

Berlin, AKademie-Verlag.--Gottfried Wilhelm Leibniz: Sämtliche Schriften und Briefe

herausgegeben von der Deutschen Akademie der Wissenschaften zu Berlin (G. H. R.

Parkinson) - $\quad$ - $\quad$ - $\quad$ - $\quad$ - $\quad$ - $\quad$ - $\quad$ - $\quad$ - $\quad$ - 294

BongIE, Laurence.-David Hume: Prophet of the Counter-Revolution (D. O. Thomas) 179

CAsEY, John. - The Language of Criticism (Peter Jones) - - $\quad$ - $\quad-\quad 65$

Coval, S. -Scepticism and the First Person (Antony Flew) - - - - 170

DE DeUgD, C.-The Significance of Spinoza's First Kind of Knowledge (Martha Kneale) 293

Dommeyer, Frederick (Ed.)-Current Philosophical Issues, Essays in Honour of Curt

John Ducasse (A. C. Ewing) -

Ehrenzweig, Anton.-The Hidden Order of Art (H, Osborne) - - - $\quad-396$

HAINes, Nicolas.-Freedom and Community (A. R. Beck) - - - - - $\quad 383$

HAMBURGer, Max.-Morals and Law: The Growth of Aristotle's Legal Theory (A. R.

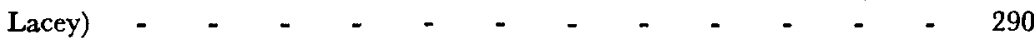

HAMPsHIRE, Stuart.-Freedom of the Individual (R. Edgley) - - - - $\quad-74$

Joske, W. D.-Material Objects (Don Locke) - - $\quad$ - $\quad$ - $\quad-\quad$ - 168

KERNER, George.-The Revolution in Ethical History (D. Z. Phillips) - - 68

KLAGes, Ludwig.-Ausdruckskunde (Sämtliche Werke Vol.6) (K. Mitchells) - 174

Kotarbinski, Tadeusz.-Praxiology-An Introduction to the Science of Efficient Action

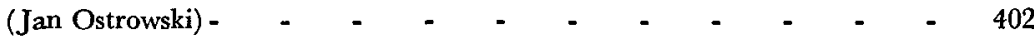

LLoxd, G. E. R.-Polarity and Analogy. Two Types of Argumentation in Early Greek

Thought (David Robinson) - - $\quad$ - $\quad$ - $\quad$ - $\quad$ - $\quad$ - $\quad$ - 288

Locke, Don.-Perception and our Knowledge of the External World (J. M. Hinton) 387

LucAs, J. R.-The Principles of Politics (Alan Ryan) - - - - - $\quad$ - 300

MAcINTYRE, Alasdair.-A Short History of Ethics (R. S. Downie) - - $\quad-67$

Mrtchell, Basil.-Law, Morality and Religion in a Secular Society (R. M. Hare) - 379

Monro, D. H.-Empiricism and Ethics (Bernard Mayo) - $-\quad$ - $\quad$ - $\quad-69$

Munsat, Stanley.-The Concept of Memory (E. J. Furlong) - $\quad-\quad$ - $\quad-169$

PhILlips, D. Z. (Ed.) -Religion and Understanding (E. L. Mascall) - - - 287

PowelL, Betty.—Knowledge of Actions (Gary Iseminger) - - - - - 71

PRESLY, C. F. (Ed.) - The Identity Theory of Mind (Don Locke) - - - 385

SABRA, A. I.-Theories of Light from Descartes to Newton (A. E. Best) - $\quad$ - 291

SAXENA, S. K.- Studies in the Metaphysics of Bradley (Richard Wollheim) - $\quad$ - 394

SchröDer, Hans Eggert.-Ludwig Klages-Die Geschichte seines Lebens: Die Jugend

(Sämtliche Werke Supplement Part 1) (K. Mitchells) - - - - 174

SkoLIMowskı, Henryk._-Polish Analytical Philosophy (Z. A. Jordan) - - $\quad-399$ 
Soltis, J. F.-Seeing, Knowing and Believing (R. J. Hirst) - - - - $\quad-389$

TAYLOR, Richard.-Action and Purpose (Gary Iseminger) - - - - 73

Vesey, G. N. A.-The Embodied Mind (Errol Bedford) - - - - 172

WeInBERG, Julius.-Abstraction, Relation and Induction: Three Essays in the History of

Thought (Rita Gupta) - - $\quad$ - $\quad$ - $\quad$ - $\quad$ - $\quad$ - 395

Wurte, Alan.-The Philosophy of Mind (Anthony Palmer) - - - - 172

Wiggins, David.-Identity and Spatio-Temporal Continuity (Antony Flew) - - 298

Williams, Bernard and Monrefrore, Alan.-British Analytical Philosophy

(Russell Grice) - $\quad$ - $\quad$ - $\quad$ - $\quad$ - $\quad$ - $\quad$ - $\quad$ - $\quad$ - 166

ZwEIG, Arnulf (Ed.).-Kant: Philosophical Correspondence 1759-99 (P. F. Strawson) 392

\section{INSTITUTE NOTICES}

Changes of Address

Conference at Southampton

Contributions to Philosophy

Lecture Programme 1968

Lecture Programme 1968/9

Members' Subscriptions -

New Centres of the Institute

Notes on Contributors -

Note to Publishers -

Philosophical Essay Competition

Royal Institute of Philosophy Annual Book Competition

Royal Institute of Philosophy Lectures

Visiting Philosophers
PAGE

- $83,187,307$

$-187,306,410$

- $83,187,307$

- $\quad$ - 81

- $\quad 305,409$

- $80,186,304$

410

$81,188,305,409$

- $83,187,307$

- $\quad-307$

$82,187,306,410$

187

$81,187,306,410$ 